Educated at Trinity College, Cambridge, he became house physician at 'Barts' during 1909-10. He acted as surgeon in the Red Crescent Mission to Turkey in the Balkan War of 1911-12, and after an interval of general practice at Wisbech became captain in the R.A.M.C., and in this capacity served in France, Mesopotamia and Persia. After the War of 1914-18 he took up a post on the resident staff at the Maudesley Hospital, and it was in connexion with his psychiatric work that he became, during 1919-22, assistant to Prof. (then Dr.) C. G. Jung in Zurich.

This was the turning point in Baynes'career. Henceforth his energies were devoted, both through the practice of psychotherapy and through the printed word as well as by means of numerous addresses to public and private bodies, to the dissemination of Jung's psychological doctrines. He not only translated Jung's major scientific work "Psychological Types" and edited and translated his "Contributions to Analytical Psychology" and "Two Essays on Analytical Psychology", but also wrote, in addition to numerous papers on psychiatry, medicine and folklore, a 900-page work entitled "Mythology of the Soul", and a last work on "Germany Possessed".

Baynes also organized and took part in the expedition which Jung made to East Africa during 1925-26 for the purposes of psychological research among the Massai tribes of Mount Elgon in Kenya.

Psychologists are apt to be thought of as formidable, if at times misguided, intellectuals. . Baynes was far removed from such a category. Largehearted as well as large-limbed, he added to his technical knowledge a warmth and sympathy that gave heart and assurance to those whom he helped to find their way, through the labyrinthine passages of the soul, towards that state of integration which results from a full recognition of the healing factors that lie buried in the collective unconscious in which he was such a firm believer. His loss is keenly felt by numerous patients and yet more numerous friends, and not least by the members of the Analytical Psychology Club in London, which he founded and led until his untimely death in full vigour at the comparatively young age of sixty-two.

JOHN LAXARD.

\section{Dr. L. F. Barker}

Dr. Leweliys FrankutN Barker, the eminent American anatomist and physician, who died after a long illness at Baltimore on July 13, was born at Norwich, Ontario, on September 16, 1867. He received his medical education at Toronto, Leipzig, Munich and Berlin, and qualified in 1890 at Toronto, where he worked at the general hospital for a year, and from 1894 until 1900 was attached to the Johns Hopkins University as associate professor of anatomy and pathology. From 1900 until 1955 he was professor of anatomy at Rush Medical College, Chicago, and for the next eight years was professor of medicine and chief physician at Johns Hopkins Hospital; he was appointed emeritus professor in 1921.

Prof. Barker was a prolific writer both on anatomical and medical subjects. His anatomical work included a translation of Spalteholz's "Hand Atlas of Human Anatomy" (1933), "Laboratory. Manual of Human Anatomy" conjointly with Dean DeWitt Lewis and D. G. Revell (1904), and "Anatomical Terminology with special reference to the B.N.A." (1907); his chief medical works were
"Tuesday Clinics at Johns Hopkins Hospital" (1922) and "Clinical Diagnosis of Internal Diseases" (1923), "Degenerative Diseases" with T. P. Sprunt (1925) and "Rheumatism; its Meaning and its Menace" (1926). He was also editor of "Endocrinology and Metabolism", by ninety-eight contributors (1922-24), in which he wrote part of the section on the parathyroid glands. His last works were "Psychotherapy" (1940) and his autobiography entitled "Time and the Physician" (1942).

In 1931-32 in honour of his sixty-fourth birthday, International Clinics published a Lewellys Barker Festschrift to which more than forty medical men contributed, including the well-known historian Fielding $H$. Garrison, who summarized his character as follows: "An austere devotion to duty and the things of the mind is set off by a distinction of appearance, a charm of personality, an hospitable nature, an open-minded freedom from prejudice, an innate kindliness of disposition, which are by no means least among the attributes of the beloved physician".

He received many honours, being hon. M.D. of the University of Toronto and LL.D. of Queen's University, Kingston, Ontario, and McGill University, Montreal. He was vice-president of the American Medical Association (1916-17), president of the Association of American Physicians and the American Neurological Association. He also enjoyed a European reputation, being foreign member of the Budapest Royal Society of Physicians, the German Society for Internal Medicine and Children's Diseases, the MedicoChirurgical Society of Edinburgh and the Swedish Medical Society. J. D. RolLESTON.

\section{Dr. H. C. H. Townend}

Dr. Herbert Charles Henry Townend, who was accidentally killed on August 19, was born in London on March 18, 1896, and was educated privately. In 1915, he enlisted as a private in the Honourable Artillery Company and after receiving a commission in the London Regiment was attached to the Royal Air Force as an observer and served in Salonika, Egypt and Palestine. On returning to civil life, in 1919, he became a student at the Northampton Polytechnic, University of London, and obtained the B.Se.(Eng.) (Lond.) degree, with first-class honours, in 1923. In October of that year he joined the staff of the National Physical Laboratory as a scientific officer. He took part in experimental work in the Aerodynamics Department covering a number of different subjects, but was best known to the outside world as the inventor of the Townend ring, a cowling device used to reduce the drag of the exposed cylinders of air-cooled engines. He made this discovery by accident when engaged on work with quite a different object, a chance observation directing his thoughts in a direction which ultimately led to the development of the ring. Townend was granted a patent on the device and it was at one time very widely used. For his work in this sphere he was awarded the Silver Medal of the Royal Aeronautical Society in 1931 and was awarded a D.Sc.(Eng.) (Lond.) in 1932. Dr. Townend was elected an associate fellow of the Royal Aeronautical Society in 1930 and a fellow in 1933. He was also an honorary scientific member of the Institute of the Aeronautical Sciences of the United States.

Townend's greatest contribution to the service of aerodynamics, however, was his fundamental study 
of the properties of turbulent flow. He devised an exquisite technique in which tiny spots of hot air were produced by minute electric sparks at various points in the field of flow to ke examined, and the subsequent motion of these 'hot spots', as he called them, was observed by cinema-photography. By these means he was enabled to follow the details of the turbulent motion, and the results of his investigations have been of great value in the subsequent development of the subject. $\mathrm{He}$ was a brilliant experimenter, one of those rare men who can improvise apparatus out of almost nothing, fit it up with their own hands, and produce important results by its use. This characteristic showed itself also in his private life, for one of his favourite hobbies was the invention and construction of very clever, but very simple, mechanical toys, some of which reached the Patent Office and the general public.

In 1937, Townend left the National Physical Laboratory and joined the staff of the Admiralty as an adviser on aerodynamic problems. The nature of his work was now completely changed, and instead of making experiments himself on a particular subject, he found himself supervising the experimental work of others and taking a broad view of the whole field of aerodynamics as it affected the problems of the Fleet Air Arm. That he was as successful in this as he had been as an original investigator is ample testimony to his great gifts and his clear vision. $\mathrm{He}$ maintained a very close contact with the National Physical Laboratory and was a frequent visitor to his many friends and former collaborators there. $\mathrm{He}$ had a delightful personality, and was a very interest- ing conversationalist. His many friends will feel a deep personal loss, and the science of aerodynamics has undoubtedly lost one of its most brilliant exponents.

WE regret to announce the following deaths :

Dr. J. J. C. Bradfield, C.M.G., Australian representative on the Council of the Institution of Civil Engineers during 1936-39, formerly chief engineer of the Sydney Harbour Bridge, aged seventy-five.

Prof. A. E. Bunge, professor of statistics in the University of Buenos Aires and director-general of national statistics, aged sixty-three.

Mr. Paul R. Crimp, student probationer at the Laboratory, Plymouth, and whaling officer, Ministry of Agriculture and Fisheries, in North Africa, aged thirty-one.

Prof. H. Lundborg, professor of racial biology in the University of Uppsala.

Prof. J. M. MacFarlane, emeritus professor of botany in the University of Pennsylvania, aged eighty-seven.

Dr. E. J. H. Mackay, the well-known archæologist, on October 2, aged sixty-three.

Prof. Peter Mühlens, director of the Bernard Nocht Institute for Naval and Tropical Diseases, Hamburg, aged sixty-seven.

Prof. A. A. Read, emeritus professor of metallurgy in the University College of South Wales and Monmouthshire, Cardiff, on September 24, aged seventy. five.

\section{NEWS and VIEWS}

Fisheries of Mauritius: Appointment of Dr. J. F. G.
Wheeler

Dr. J. F. G. WhEELER, lately director of the Bermuda Biological Station for Research Incorporated, has been appointed marine biologist in Mauritius. Dr. Wheeler was assistant lecturer in zoology at the University of Bristol and during 192431 was naturalist on board the R.R.S. Discovery engaged on whaling investigations in the Antarctic, before taking up his duties at Bermuda. The object of the Mauritius appointment is to obtain for Mauritius the services of an expert to examine the marine and freshwater fisheries with a view to the possible establishment of a permanent fisheries control organization to improve existing nutrition standards of the islanders. It is hoped that Dr. Wheeler's researches may be a prelude to the establishment of a Fisheries Department for Mauritius as a permanent institution. The present scheme for the development of the island's fisheries has been made possible by a free grant up to $£ 4,500$ under the Colonial Development and Welfare Act, 1940.

\section{Copernicus}

The Selby Lecture, delivered on May 27 by Sir Harold Spencer Jones, the Astronomer Royal, at Cardiff was on Copernicus (Cardiff: Univ. of Wales Press Board. 1s. 6d. net). The lecture covers much the same ground as the article by the Astronomer Royal contributed to Nature of May 22, but a few additional points are worth noticing. For a long time after the publication of "De Revolutionibus", it was believed that Copernicus was the author of the prefatory note which stated that it was not necessary that the hypotheses advocated should be true or even probable; it was sufficient that they should lead to results in agreement with observation. Although Osiander wrote the prefatory note without Copernicus's knowledge, this was not known at the time, and there was a widespread belief in the six. teenth century that Copernicus had advanced his theory merely as a mathematical device which he did not consider corresponded to any physical reality. Another very interesting matter should be mentioned. Although Copernicus accepted the value for the solar parallax found by Hipparchus, namely, 3', which implied that an astronomical unit was about one twentieth of its true value, yet the relative mean distances of the planets from the sun, obtained by Copernicus, were remarkably accurate when com. pared with the most recent determinations. Objec. tions to the Copernican system arose inter alia on the question of the distance of the stars, and opponents contended that Copernicus had assumed a great distance for the stars merely to obviate the serious difficulty that they showed no parallax. This was the main reason for the rejection of the Copernican system by Tycho Brahe, and his substitution of a geocentric system in which the sun and moon revolved round the earth, but all the other planets revolved round the sun. Copernicus would not com. mit himself to any definite statement regarding the infinite distance or otherwise of the stars, and Bruno is usually regarded as the pioneer of the conception of an infinite universe and an infinite number of 